\title{
26. IN SEARCH OF A SUBSURFACE BIOSPHERE AT A SLOW-SPREADING RIDGE ${ }^{1}$
}

\author{
A.-L. Reysenbach, ${ }^{2}$ N.G. Holm, ${ }^{3}$ K. Hershberger, ${ }^{4}$ D. Prieur, ${ }^{5}$ and C. Jeanthon ${ }^{5}$
}

\begin{abstract}
Microbiological and molecular examination of cores from the Trans-Atlantic Geotraverse (TAG) hydrothermal field (Leg 158) indicated that, in the samples analyzed and within the detection limits of the methods used, there was no significant microbial biomass that could be indicative of deep subsurface biological communities at this site. Two samples from the upper 100 $\mathrm{cm}$ of core produced enrichment cultures of hyperthermophilic sulfur-reducing microorganisms. However, the possibility that these organisms were entrained from the surface of the hydrothermal field during coring cannot be ruled out. It was concluded that, although an extensive subsurface biosphere might exist elsewhere at TAG, no conclusive evidence for such an environment was obtained from the samples analyzed during Leg 158 and the challenge to explore this tantalizing hypothesis remains open.
\end{abstract}

\section{INTRODUCTION}

Hydrothermal circulation at ridge crests plays a dynamic role in determining the physical, chemical, and biological interactions at these sites. It is well established that the diverse biological communities associated with hydrothermal venting are based on chemolithotrophic utilization of reduced constituents from hydrothermal fluids. Surficial sampling of deep-sea hydrothermal vent communities has greatly increased our understanding of these ecosystems, yet our knowledge of a significant part of these systems, the subsurface, is severely limited. Nevertheless, there is growing consensus that a substantial subsurface biosphere may exist (Gold, 1992; Deming and Baross, 1993; Pedersen 1993; Thorseth et al., 1995) and there is growing indirect evidence that deep-sea hydrothermal vents are "windows" into a vast subsurface biosphere (Deming and Baross, 1993). For example, hydrothermal fluid compositions from the Endeavour Segment of the Juan de Fuca Ridge suggested underlying organic compounds (Lilley et al., 1993) and contained DNA (Straube et al., 1990). Many of the hyperthermophilic microorganisms that have been isolated were isolated directly from venting fluid samples (e.g., Reysenbach and Deming, 1991) and these isolates are able to grow at pressures considerably greater than those encountered at the seafloor, suggesting an ability to grow in subsurface habitats much deeper than accessible hydrothermal formations. Several of these isolates have enzymes that are stable at much higher temperatures than those at which they were grown (e.g., Bryant and Adams, 1989; Baross and Deming, 1995). It remains unclear whether these microorganisms are indigenous or transient to these environments, yet it is unlikely that they are able to grow in the fast-flowing fluids. This suggests that the organisms may have originated from areas underlying the active seafloor vents or from recharge areas in the hydrothermal system. Furthermore, in situ sampling devices ("vent caps") placed on top of hydrothermal vents have sampled a rich diversity of microorganisms (A.-L. Reysenbach, unpubl. data) that may have been flushed into the sampler from underlying subsurface communities.

${ }^{1}$ Herzig, P.M., Humphris, S.E., Miller, D.J., and Zierenberg, R.A. (Eds.), 1998. Proc. ODP, Sci. Results, 158: College Station, TX (Ocean Drilling Program).

${ }^{2}$ Department of Biochemistry and Microbiology, Cook Campus, Rutgers University, New Brunswick, NJ 08903, U.S.A. alr@imcs.rutgers.edu

${ }^{3}$ Department of Geology and Geochemistry, Stockholm University, S-106 91 Stockholm, Sweden.

${ }^{4}$ Biology Department, Indiana University, Bloomington, IN 47405, U.S.A

${ }^{5}$ Station Biologique, B. P. 74, F-29682 Roscoff cedex, France.
The presence of microbial life in terrestrial subsurface environments has been reported in deep formations associated with petroleum and sulfur deposits and with deep aquifers (Ghiorse and Wilson, 1988; Stetter et al., 1993; Szewzyk et al., 1994; L'Haridon et al., 1995, Stevens and McKinley, 1991). Evidence is accumulating from some deep-sea drilling operations (e.g., Ocean Drilling Program [ODP] Legs 112 and 128; Cragg et al., 1990; Cragg et al., 1992), that similar subsurface life exists in sediments beneath the deep ocean. The presence of bacterial DNA in glass from pillow lavas from ODP Hole 896A, Leg 148, was used to estimate that the microorganisms were at a depth of at least $237 \mathrm{~m}$ in the volcanic basement at a temperature of $70^{\circ} \mathrm{C}$ (Giovannoni et al., 1996; Furnes et al., 1996). Recently, bacterial distributions associated with deep sediments influenced directly by hydrothermal systems (Middle Valley, Juan de Fuca Ridge) were studied for the very first time (Cragg and Parkes, 1994). The bacterial numbers correlated in a complex way with chlorinity and temperature within the sediments, and the vent fluid flow. This relationship confirmed the response of bacteria to hydrothermal fluid flux in the subsurface within sediments; however, no study has attempted to examine the distribution of bacteria within an unsedimented hydrothermal vent field, which would be more directly indicative of inter-crustal microbial communities because the hydrothermal system is not overlaid by organic-rich sediments.

During ODP Leg 158, a series of cores was obtained from holes drilled into the large hydrothermally active mound of the TransAtlantic Geotraverse (TAG) hydrothermal field providing an excellent opportunity to test the hypothesis whether, within the detection limits of the methods used, an active microbial subsurface biosphere could be detected at this site. Here we report the search for evidence for microbial life in the unsedimented hydrothermal vent system at the TAG hydrothermal mound.

\section{MATERIALS AND METHODS}

\section{Site Description}

The TAG hydrothermal field is located on the Mid-Atlantic Ridge at $26^{\circ} 08^{\prime} \mathrm{N}$ and at a depth of $3650 \mathrm{~m}$. The hydrothermal mound is approximately $50 \mathrm{~m}$ high and $200 \mathrm{~m}$ in diameter. Two mineralogically distinct areas reflect different, yet related, venting on the mound (Humphris et al., 1995). High-temperature venting $\left(>360^{\circ} \mathrm{C}\right)$ occurs from the upper terrace chalcopyrite-anhydrite-rich chimneys. On the lower platform, the venting is lower in temperature $\left(260-300^{\circ} \mathrm{C}\right)$, the fluids are zinc rich and the chimneys are dominated by sphalerite. De-

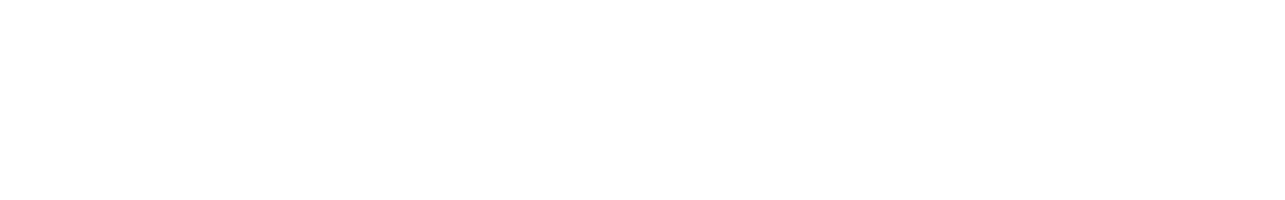


tailed mineralogical descriptions of the cores obtained from these areas are provided elsewhere in this volume. Samples analyzed varied depending on location but were largely pyrite breccias, varying in their silica or anhydrite content. As no hydrological data were available for the site, it was assumed that if microorganisms were present they would be near fluid flow or within porous rock and therefore, wherever possible, sampling was restricted to samples containing veins indicative of fluid flow.

\section{Shipboard Handling}

Once the core was brought on board, samples for microbiological analyses were taken as aseptically as possible. Subsamples were frozen immediately for DNA analyses. For inocula into growth media, samples were maintained under nitrogen and were ground and inoculated anaerobically into growth media for methanogens (Widdel, 1992) and for sulfur-reducing hyperthermophiles (Erauso et al., 1993). Additional samples were stored under nitrogen at $4^{\circ} \mathrm{C}$ in sterile glass vials for shore-based inoculation of enrichment media for thermophiles. Samples were fixed in 3\% paraformaldehyde (v/v) in sterile artificial seawater (ASW) for scanning electron microscopy and fluorescence microscopy. Samples for in situ hybridization studies were either frozen immediately or washed in ASW, then placed in $4 \%$ paraformaldehyde in ASW for $6 \mathrm{hr}$, rinsed in phosphate buffered saline (PBS), and stored in 50\% ethanol in PBS at $4{ }^{\circ} \mathrm{C}$ until the samples reached the laboratory, where they were stored at $-20^{\circ} \mathrm{C}$.

\section{Microscopy}

Paraformaldehyde-fixed samples were stained with 4',6'-diamidino-2-phenylindole (DAPI) for 5 min (Porter and Feig, 1980), and viewed using a Nikon Microphot-FXA photomicroscope. Controls without DAPI were used to distinguish between background fluorescence and possible stained cells. For scanning electron microscopy, paraformaldehyde-fixed samples were passed through an ethanol dehydration series $(10 \%-100 \%)$, critical point dried, mounted on scanning electron microscope stubs and sputter-coated with gold-palladium. The samples were viewed in a Cambridge 5250 MK2 scanning electron microscope.

\section{In Situ Hybridization}

Ethanol-fixed samples were mixed by using a vortex, resuspended in PBS, and a subsample ( $30 \mu \mathrm{L})$ was smeared onto gelatin-coated glass slides (Giovannoni et al., 1988) and air dried. In situ hybridizations were done as described by DeLong et al. (1989) using both bacterial-specific and universal fluorescein-labeled probes (Giovannoni et al., 1988) and viewed directly on a Nikon Microphot-FXA photomicroscope.

\section{DNA Extraction}

Samples from cores were rinsed in sterile seawater, and wherever possible, a subsample from the inner portion of a sample was taken. The samples were first ground with a sterile pestle and mortar. DNA was extracted and purified according to the methods described by Zhou et al. (1996) and the method of Barns et al. (1994), which was developed specifically for hydrothermal sediments.

\section{Shore-Based Enrichments of Hyperthermophiles}

All samples were kept anaerobic during processing. Hungate tubes containing $4.5 \mathrm{~mL}$ of YPS-medium for sulfur-reducers (Erauso et al., 1993) were inoculated with approximately $1 \mathrm{~cm}^{3}$ of sample, pressurized with $\mathrm{N}_{2}(100 \mathrm{kPa})$, and incubated without shaking at $80^{\circ} \mathrm{C}$ until growth was observed. The samples were used as inocula for enrichment of methanogens $(50-\mathrm{mL}$ vials containing $4.5 \mathrm{~mL}$ of medium (Jones et al., 1989) with a $\mathrm{H}_{2} / \mathrm{CO}_{2}$ as the gas phase), thiosulfate-reducers (Hungate tubes containing $4.5 \mathrm{~mL}$ of YP-medium containing $10 \mathrm{mM}$ thiosulfate with $\mathrm{N}_{2}(100 \mathrm{kPa})$ [Jeanthon et al., 1995]) and sulfate-reducers (stoppered $25-\mathrm{mL}$ bottles containing $4.5 \mathrm{~mL}$ of YP basal solution supplemented with $0.05 \%$ yeast extract, $10 \mathrm{mM}$ lactate, and $15 \mathrm{mM}$ acetate with a $\mathrm{N}_{2} / \mathrm{CO}_{2}$ [80/20] gas phase [Widdel, 1992]). All media were incubated at $75^{\circ} \mathrm{C}$ without agitation.

\section{RESULTS}

A summary of the results obtained is presented in Table 1.

\section{Microscopy}

\section{Direct Counts}

Cell numbers were too low to determine a reliable cell count. Furthermore, autofluorescence interference of minerals made it very difficult to distinguish between autofluorescence and DAPI-stained cells (Fig. 1, see arrows). Thin rod-like structures appeared to dominate, although some diffuse staining of Thermococcus-like cocci structures were observed (Fig. 1B). However, the background autofluorescence in these samples is problematic for interpretation. In some cases, dividing rods were observed (Fig. 1J). These narrow rods are reminiscent of Thermophilum-like cells.

\section{Scanning Electron Microscopy}

An example of a scanning electron micrograph of a sample is presented in Figure 2. Electron microscopy did not reveal the presence any microbial structures. Figure 2 indicates similar needle-like structures or potential Thermophilum-like cells as those observed with DAPI-stained preparations. The thread-like coating on one sample (data not shown) did not appear to be biological.

\section{In Situ Hybridization}

In order to confirm the observations from DAPI-stained preparations, in situ hybridization using the small subunit-specific rRNA probes were performed on a selection of samples. Although under phase contrast microscopy, similar microbial-like structures to those seen with DAPI-staining were seen (Fig. 1), the fluorescein-labeled probes did not hybridize to these "organisms." Either these organisms were too inactive (low ribosome numbers), and therefore the probe was not sensitive enough, or the probe was not taken up by the cells, or the cell-like structure is not an organism, but an artifact. Some slides that were viewed had cell-like structures that autofluoresced, and therefore no conclusions could be drawn from these preparations. Fluorescence, as a result of the presence of methanogens, could not be ruled out.

\section{DNA Extraction}

No DNA was obtained from the samples extracted. To ascertain that the DNA was not being lost during the extraction procedure, a control using Escherichia coli cells added to a subsample was used, and the DNA extracted from this sample (Table 1).

\section{Enrichments}

Shipboard enrichments for methanogen and sulfur-reducers were done at $60^{\circ}, 80^{\circ}$, and $90^{\circ} \mathrm{C}$. Growth was monitored microscopically. Growth at $80^{\circ} \mathrm{C}$ in a medium for sulfur-reducers was obtained from one sample (Sample 158-957B-1R-1, 100-103 cm). The initial enrichment was a mixed culture of cocci and short rods. However, sub- 
Table 1. List of ODP 158 samples analyzed for microorganisms and DNA.

\begin{tabular}{|c|c|c|c|c|c|}
\hline $\begin{array}{l}\text { Core, section, } \\
\text { interval }(\mathrm{cm})\end{array}$ & $\begin{array}{l}\text { Approximate depth } \\
\text { (mbsf) }\end{array}$ & Dominant lithology* & Cells & DNA & Growth \\
\hline \multicolumn{6}{|l|}{ 158-957B- } \\
\hline $1 \mathrm{R}-1,15-20$ & 0.15 & Surface material & - & - & - \\
\hline $1 \mathrm{R}-1,100-103$ & 1.0 & Surface material & + & - & - \\
\hline $4 \mathrm{R}-1,8-10$ & 19.9 & Clay horizon & - & - & - \\
\hline \multicolumn{6}{|l|}{ 158-957C- } \\
\hline $7 \mathrm{~N}-1,24-25$ & 19.5 & $\begin{array}{l}\text { Pyrite-anhydrite breccia } \\
\text { with anhydrite veins }\end{array}$ & - & - & - \\
\hline $7 \mathrm{~N}-1,67-68$ & 19.9 & $\begin{array}{l}\text { Pyrite-anhydrite breccia } \\
\text { with anhydrite veins }\end{array}$ & - & - & - \\
\hline $7 N-2,36-37$ & 20.8 & $\begin{array}{l}\text { Pyrite-anhydrite breccia } \\
\text { with anhydrite veins }\end{array}$ & - & - & - \\
\hline $7 \mathrm{~N}-3,27-28$ & 22.1 & $\begin{array}{l}\text { Pyrite-anhydrite breccia } \\
\text { with anhydrite veins }\end{array}$ & - & - & - \\
\hline $11 \mathrm{~N}-1,39-42$ & 30.7 & Pyrite-silica breccia & - & - & - \\
\hline $13 \mathrm{~N}-2,10-13$ & 38.6 & Pyrite-silica breccia & - & - & - \\
\hline $14 \mathrm{~N}-1,74-75$ & 40.2 & Pyrite-silica breccia & - & - & - \\
\hline $14 \mathrm{~N}-2,49-50$ & 40.9 & Pyrite-silica breccia & - & - & - \\
\hline \multicolumn{6}{|l|}{$158-957 \mathrm{~F}-$} \\
\hline $1 \mathrm{~N}-1,19-21$ & 0.19 & $\begin{array}{l}\text { Massive pyrite breccia, } \\
\text { chalcopyrite }\end{array}$ & \pm & - & - \\
\hline $2 \mathrm{~N}-1,2-3$ & 5.5 & Massive pyrite breccia & \pm & - & - \\
\hline \multicolumn{6}{|l|}{$158-957 \mathrm{H}-$} \\
\hline $1 \mathrm{~N}-1,60-73$ & 8.93 & Porous pyrite breccia & - & - & - \\
\hline $3 \mathrm{~N}-1,22-26$ & 18.13 & Porous nodular pyrite breccia & \pm & - & - \\
\hline $5 \mathrm{~N}-2,48-58$ & 27.89 & Silicified wallrock breccia & - & - & - \\
\hline \multicolumn{6}{|l|}{$158-957 \mathrm{~K}-$} \\
\hline $1 X-1,39-45$ & 0.39 & $\begin{array}{l}\text { Porous massive pyrite with } \\
\text { red and gray chert }\end{array}$ & - & - & - \\
\hline \multicolumn{6}{|l|}{$157-957 \mathrm{M}-$} \\
\hline $1 \mathrm{R}-1,1-5$ & 0 & $\begin{array}{l}\text { Porous massive pyrite with } \\
\text { red and gray chert }\end{array}$ & - & - & - \\
\hline $1 \mathrm{R}-1,49-54$ & 0.5 & $\begin{array}{l}\text { Porous massive pyrite with } \\
\text { red and gray chert }\end{array}$ & - & - & - \\
\hline \multicolumn{6}{|l|}{ 158-957P- } \\
\hline $12 \mathrm{R}-1,0-4$ & 52.0 & $\begin{array}{l}\text { Pyrite silica breccia with } \\
\text { angular basalt }\end{array}$ & + & - & - \\
\hline $12 \mathrm{R}-1,138-140$ & 52.13 & $\begin{array}{l}\text { Pyrite silica breccia with } \\
\text { angular basalt }\end{array}$ & + & - & - \\
\hline \multicolumn{6}{|l|}{ 158-957Q- } \\
\hline $1 \mathrm{R}-1,0-5$ & 5.49 & Iron oxides partially silicified & - & - & - \\
\hline $1 \mathrm{R}-4,112-116$ & 6.39 & Iron oxides partially silicified & \pm & - & - \\
\hline Control $\dagger$ & & & ++ & + & + \\
\hline
\end{tabular}

Notes: $*=$ detailed descriptions in Humphris, Herzig, Miller, et al., 1996. Cell symbols: $+=$ apparent detection of cells stained with the DNA-specific stain, DAPI; $\pm=$ uncertain; $-=$ no cells. DNA symbols: $-=$ no detected DNA with the methods used; $+=$ DNA detected. Growth symbols: $+=$ growth in enrichment culture media; $-=$ no detectable growth. $\dagger=$ Escherichia coli cells added to subsample of Sample 158-957F-1N-1, 19-21 cm.

sequent transfers of this enrichment were unsuccessful, and the culture was lost. We were able to reenrich for this mixed culture in the laboratory. This culture was a mixture of nonsporulating rods and paired cocci. These initial enrichments were successfully transferred into the same medium at $65^{\circ}, 75^{\circ}$, and $85^{\circ} \mathrm{C}$. No growth occurred at $95^{\circ} \mathrm{C}$. Paired cocci were observed in the subcultures; however, the nonsporulating rods did not regrow. We are currently characterizing this hyperthermophilic culture more fully. Growth at $65^{\circ}, 75^{\circ}$ and $85^{\circ} \mathrm{C}$ also occurred in a sulfur-reducing medium inoculated with Sample 158-957F-1N-1, 19-21 cm. Under phase-contrast microscopy, this enrichment consisted of regular cocci occurring predominantly in pairs, typical of the Thermococcales group.

\section{DISCUSSION}

The existence of a subsurface biosphere at deep-sea hydrothermal vents is a tantalizing yet problematic issue to resolve. Sampling aseptically is nearly impossible, although all precautions were taken during this study to minimize contamination once cores reached the surface. Furthermore, we hypothesized that microbial communities, in subsurface sites, occur along thermal gradients, and where there is fluid flow. Therefore, wherever possible, sampling efforts were concentrated along veins or in porous sulfides. Additionally, a combination of classical and molecular tools was used to address the problem as thoroughly as possible. It is well established that only a small portion of naturally occurring organisms usually grow in laboratory enrichments (e.g., Amann et al., 1995); however, positive growth does provide definitive proof of viable organisms. The molecular tools used should have identified viable and dead organisms, or only DNA. The absence of detectable DNA, growth from samples obtained from the upper few centimeters of the mound, and the inconclusive microscopy results, suggest that the samples do not harbor very active microbial communities. However, it is also possible that because the samples were so rich in goethite (data not shown), the DNA was bound efficiently to this mineral and could not be detected by the methods used (Holm et al., 1993). Holm and coworkers (1993) have shown that $\mathrm{FeOOH}$ minerals like goethite are efficient scavengers of nucleotides and polynucleotides in aqueous systems. The extent of binding of the polymerized nucleotides (poly[A], poly[C], and poly[U]) is approximately double that observed for the mononucleotides, indicating that the increase in size of nucleotide molecules increases the binding efficiency (Holm et al., 1993). We did, however, attempt to overcome this problem during DNA extractions by ex- 

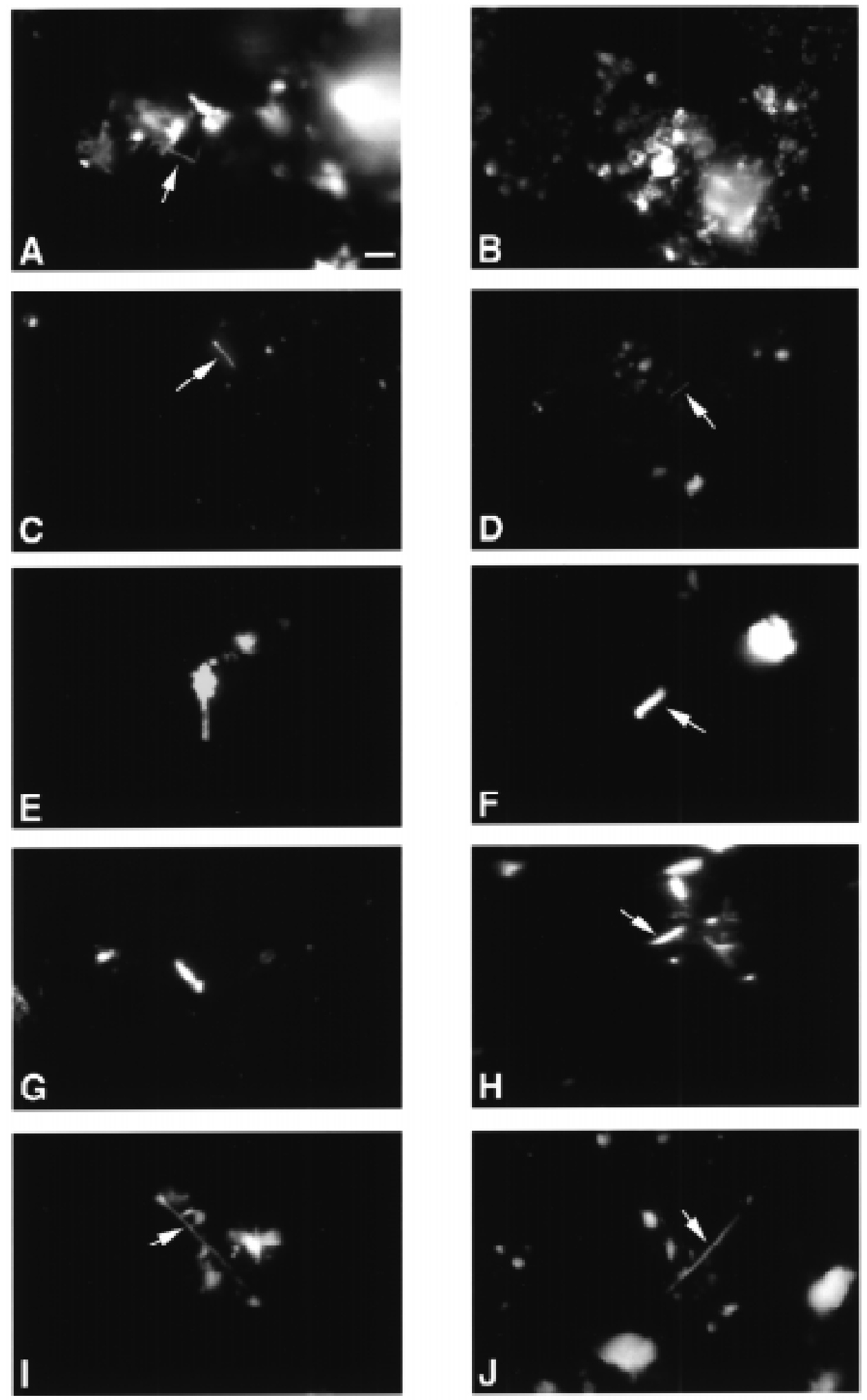

Figure 1. Photomicrographs of samples obtained with the DNA-specific stain, DAPI. A. Sample 158-957B-1R-1, 100-103 cm. B. Sample 158-957B-4R-1, 8$10 \mathrm{~cm}$. C. Sample 158-957C-7N-1, 24-25 cm. D. Sample 158-957F-2N-1, 2-3 cm. E. Sample 158-957B-4R-1, 8-10. F. Sample 158-957Q-1R-4, 112-116 cm. G. Sample 158-957Q-1R-4, 112-114 cm. H. Sample 158-957P-12R-1, 138-140 cm. I. Sample 158-957P-12R-1, 138-140 cm. J. Sample 158-957Q-1R$4,112-116 \mathrm{~cm}$. Arrows indicate putative DAPI-stained bacterial cells. Bar $=5 \mu \mathrm{m}$. 


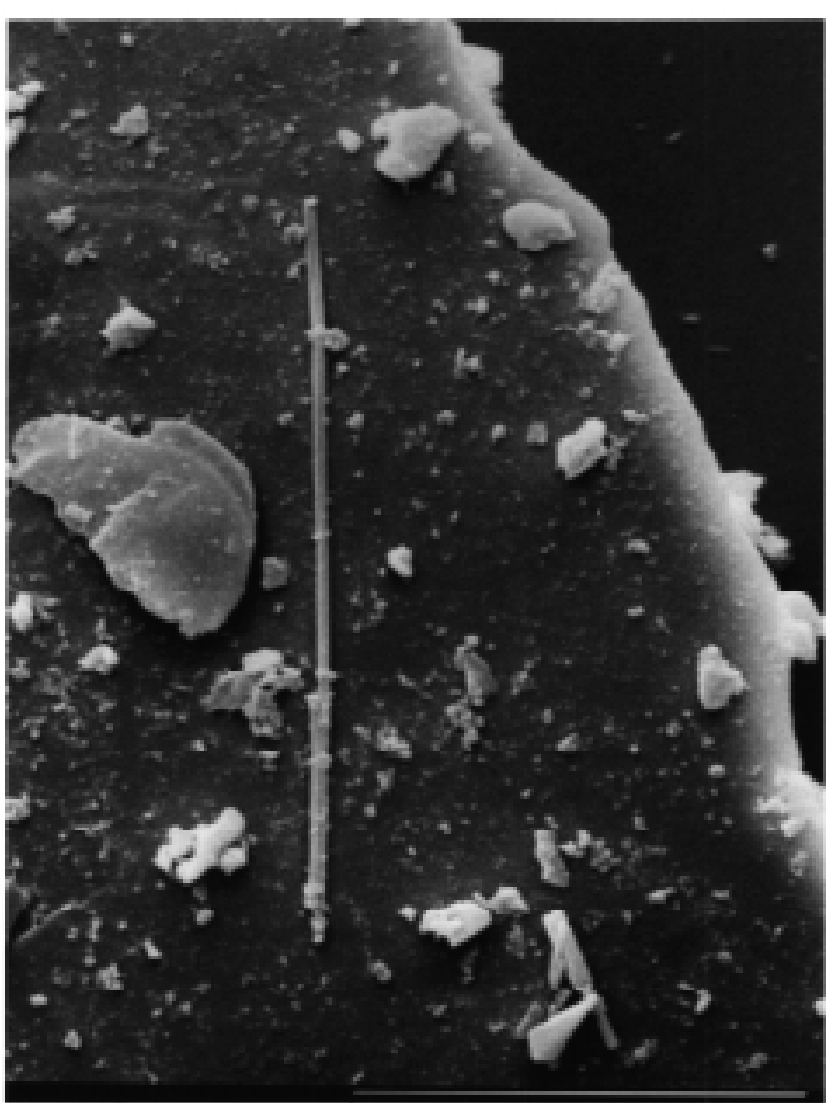

Figure 2. Scanning electron micrograph of Sample 158-957Q-1R-4, 112-116 $\mathrm{cm}$. Bar $=10 \mu \mathrm{m}$.

tracting DNA in the presence of high concentrations of the chelator, EDTA.

The absence of any convincing evidence of DNA or microbial life from the Leg 158 samples analyzed does not rule out the possibility that microbial communities exist in the deeper horizons at TAG hydrothermal field. At the nearby Snake Pit hydrothermal site, microorganisms appear to accumulate in pore spaces within sulfidic chimney walls (E. Corre, A.-L. Reysenbach, and D. Prieur, unpubl. data), and the distribution of microbial communities in sulfides is patchy (Hedrick et al., 1992; Corre et al., unpubl. data). It is therefore possible that the samples obtained for microbiological sampling during Leg 158 were in areas where these communities had not accumulated. It is also possible that the temperatures, as estimated by the mineralogy to be greater than $150^{\circ} \mathrm{C}$ (Humphris et al., 1995), are prohibitive for establishing significant biomass. Additionally, potential strict anaerobes may have escaped enrichment, and obligate barophiles were not enriched for. Hyperthermophiles have been grown under laboratory conditions at temperatures up to $110^{\circ} \mathrm{C}$ (e.g., Pledger and Baross, 1991), and although life has been reported to exist at up to $250^{\circ} \mathrm{C}$ at deep-sea hydrothermal vents (Baross and Deming, 1983), this has not been confirmed by any independent studies. Furthermore, the possibility that the drilling process of pumping gallons of seawater down the drill hole may have flushed out organisms present in the core samples. However, the noted absence of microorganisms in the samples analyzed alleviates fears that the coring procedure may contaminate samples significantly, and suggests that the precautions that were taken to obtain samples for microbiological analyses were adequate.

The results reported here do not support the hypothesis that a vast biosphere exists below TAG hydrothermal field. The growth of or- ganisms from the upper sections of the mound confirms results from enrichment cultures of sulfide chimney samples taken during submersible dives (e.g., Reysenbach and Deming, 1991) at Juan de Fuca Ridge and TAG hydrothermal field (e.g., Wirsen et al., 1993; Gilmor and Cowan, 1995). Alternatively, organisms could have been entrained from the hydrothermal vent field during core retrieval. The presence of chemical signatures suggestive of an underlying organic input into the hydrothermal fluids as reported for the Endeavor Segment of the Juan de Fuca Ridge (Lilley et al., 1993), has not been reported at TAG. Each hydrothermal site is unique, and therefore, it is entirely possible that a significant microbial biomass exists in the subsurface below other unsedimented ridges. Sedimented ridges such as at Middle Valley support microbial populations that exist and respond to thermal gradients and fluid flux (Cragg and Parkes, 1994). However, from this study, it appears that at TAG hydrothermal field, the hydrothermal venting does not represent a "window" into the deep subsurface, but more likely a glimpse into the porous few centimeters within the mound, at a scale similar to that seen within sulfide chimney walls.

\section{ACKNOWLEDGMENTS}

We thank the ODP staff and the JOIDES Resolution crew from Leg 158 for taking extra care that we received the best samples possible during Leg 158. Advice from Barry Cragg in preparations for the ODP cruise was much appreciated. Thanks to Gyongyver Levai, Tim Shank, and Allen Pooley for help with the photography, David Boone for help with the enrichments for methanogens, and Julie Kirshtein for editorial assistance. Much of this work was done in the laboratory of Norman Pace at Indiana University, and we thank him for the facilities provided. A special thanks to the patience of the Leg 158 Shipboard Scientific Party for making my (ALR) first "handson" experience with sulfide mineralogy so much fun. This work was funded in part by a grant from the JOI/WJAC Ocean Drilling Program \#158-20885b and the Swedish Natural Science Research Council \#G-GU3865.

\section{REFERENCES}

Amann, R.I., Ludwig, W., and Schleifer, K.-H., 1995. Phylogenetic identification and in situ detection of individual microbial cells without cultivation. Microbial Rev., 59:143-169.

Barns, S.M., Fundyga, R.E., Jefferies, M.W., and Pace, N.R., 1994. Remarkable Archaeal diversity detected in a Yellowstone National Park hot spring environment. Proc. Natl. Acad. Sci., 91:1609-1613.

Baross, J.A., and Deming, J.W., 1983. Growth of "black smoker" bacteria at temperatures of at least $250^{\circ}$ C. Nature, 303:423-426.

Baross, J.A., and Deming, J.W., 1995. Growth at high temperatures: isolation and taxonomy, physiology, ecology. In Karl, D.M. (Ed.), The Microbiology of Deep-Sea Hydrothermal Vent Environments: Boca Raton, FL (CRC Press), 169-217.

Bryant, F.O., and Adams, M.W.W., 1989. Characterization of hydrogenase from the hyperthermophilic archaebacterium Pyrococcus furiosus. J. Biol. Chem., 264:5070-5079.

Cragg, B.A., Harvey, S.M., Fry, J.C., Herbert, R.A., and Parkes, R.J., 1992. Bacterial biomass and activity in the deep sediment layers of the Japan Sea, Hole 798B. In Pisciotto, K.A., Ingle, J.C., Jr., von Breymann, M.T., Barron, J., et al., Proc. ODP, Sci. Results., 127/128 (Pt. 1): College Station, TX (Ocean Drilling Program), 761-776.

Cragg, B.A., and Parkes, R.J., 1994. Bacterial profiles in hydrothermally active deep sediment layers from Middle Valley (NE Pacific), Sites 857 and 858. In Mottl, M.J., Davis, E.E., Fisher, A.T., and Slack, J.F. (Eds.), Proc. ODP, Sci. Results, 139: College Station, TX (Ocean Drilling Program), 509-516.

Cragg, B.A., Parkes, R.J., Fry, J.C., Herbert, R.A., Wimpenny, J.W.T., and Getliff, J.M., 1990. Bacterial biomass and activity profiles within deep sediment layers. In Suess, E., von Huene, R., et al., Proc. ODP, Sci. Results, 112: College Station, TX (Ocean Drilling Program), 607-619. 
DeLong, E.F., Wickham, G.S., and Pace, N.R., 1989. Phylogenetic stains: ribosomal RNA-based probes for the identification of single cells. Science, 243:1360-1363.

Deming, J.W., and Baross, J.A., 1993. Deep-sea smokers: windows to a subsurface biosphere. Geochim. Cosmochim. Acta, 57:3219-3230.

Erauso, G., Reysenbach, A.-L., Godfroy, A., Meunier, J.-R., Crump, B., Partensky, F., Baross, J.A., Marteinsson, V.T., Barbier, G., Pace, N.R., and Prieur, D., 1993. Pyrococcus abyssi sp. nov., a new hyperthermophilic archaeon isolated from a deep-sea hydrothermal vent. Arch Microbiol., 160:338-349

Furnes, H., Thorseth, I.H., Tumyr, O., Torsvik, T., and Fisk, M.R., 1996. Microbial activity in the alteration of glass from pillow lavas from Hole 896A. In Alt, J.C., Kinoshita, H., Stokking, L.B., and Michael, P.J. (Eds.), Proc. ODP, Sci. Results, 148: College Station, TX (Ocean Drilling Program), 191-206.

Ghiorse, W.C., and Wilson, J.T., 1988. Microbial ecology of the terrestrial subsurface. Adv. Appl. Microbiol., 33:107-177.

Gilmor, M., and Cowan, D.A., 1995. Isolation of novel aerobic bacteria from TAG hydrothermal vent site. BRIDGE Newsl., 9:3-4.

Giovannoni, S.J., DeLong, E., Olsen, G.J., and Pace, N.R., 1988. Phylogenetic group-specific oligodeoxynucleotide probes for in situ microbial identification. J. Bacteriol., 170:720-726.

Giovannoni, S.J., Fisk, M.R., Mullins, T.D., and Furnes, H., 1996. Genetic evidence for endolithic microbial life colonizing basaltic glass/seawater interfaces. In Alt, J.C., Kinoshita, H., Stokking, L.B., and Michael, P.J. (Eds.), Proc. ODP, Sci. Results, 148: College Station, TX (Ocean Drilling Program), 207-214.

Gold, T., 1992. The deep, hot biosphere. Proc. Nat. Acad. Sci. USA, 89:6045-6069.

Hedrick, D.B., Pledger, R.J., White, D.C., and Baross, J.A., 1992. In situ microbial ecology of hydrothermal vent sediments. FEMS Microbial Ecol., 101:1-10.

Holm, N.G., Ertem, G., and Ferris, J.P., 1993. The binding and reactions of nucleotides and polynucleotides on iron oxide hydroxide polymorphs. Origins Life Evol. Biosphere, 23:195-215.

Humphris, S.E., Herzig, P.M., Miller, D.J., et al., 1996. Proc. ODP, Init. Repts., 158: College Station, TX (Ocean Drilling Program).

Humphris, S.E., Herzig, P.M., Miller, D.J., Alt, J.C., Becker, K., Brown, D., Brügmann, G., Chiba, H., Fouquet, Y., Gemmell, J.B., Guerin, G., Hannington, M.D., Holm, N.G., Honnorez, J.J., Itturino, G.J., Knott, R., Ludwig, R., Nakamura, K., Petersen, S., Reysenbach, A.-L., Rona, P.A., Smith, S., Sturz, A.A., Tivey, M.K., and Zhao, X., 1995. The internal structure of an active sea-floor massive sulphide deposit. Nature, 377:713-716.

Jeanthon, C., Reysenbach, A.-L., L'Haridon, S., Gambacorta, A., Glénat, P., Pace, N.R., and Prieur, D., 1995. Thermotoga subterranea sp. nov., a new thermophilic bacterium isolated from an oil reservoir. Arch. Microbiol., 164:91-97.
Jones, W.J., Stugard, C.E., and Jannasch, H.W., 1989. Comparison of thermophilic methanogens from submarine hydrothermal vents. Arch. Microbiol., 151:314-318.

L'Haridon, S.L., Reysenbach. A.-L., Glenat, P., Prieur, D., and Jeanthon, C., 1995. Hot subterranean biosphere in a continental oil reservior. Nature, 377:223-224.

Lilley, M.D., Butterfield, D.E., Olson, E.J., Lupton, J.E., Mackos, S.A., and McDuff, R.E., 1993. Anomalous $\mathrm{CH}_{4}$ and $\mathrm{NH}_{4}$ concentrations at an unsedimented mid-ocean ridge hydrothermal system. Nature, 364:45-47.

Pedersen, K., 1993. The deep subterranean biosphere. Earth-Sci. Rev., 34:243-260.

Pledger, R.J., and Baross, J.A., 1991. Preliminary description and nutritional characterization of a heterotrophic archaeobacterium growing at temperatures of up to $110^{\circ} \mathrm{C}$ isolated from a submarine hydrothermal vent environment. J. Gen. Microbiol., 137:203-211.

Porter, K.G., and Feig, Y.S., 1980. The use of DAPI for identifying and counting aquatic microflora. Limnol. Oceanogr., 25:943-948.

Reysenbach, A.-L. and Deming, J.W., 1991. Effects of hydrostatic pressure on growth of hyperthermophilic archaebacteria from the Juan de Fuca Ridge. Appl. Environ. Microbiol., 57:1271-1274.

Stetter, K.O., Huber, R., Blöchl, E., Kurr, M., Eden, R.E., Fielder, M., Cash, H., and Vance, I., 1993. Hyperthermophilic archaea are thriving in deep North Sea and Alaskan oil reservoirs. Nature, 365:743-745.

Stevens, T.O., and McKinley, J.P., 1995. Lithoautotrophic microbial ecosystems in deep basalt aquifers. Science 270:450-454.

Straube, W.L., Deming, J.W., Somerville, C.C., Colwell, R.R., and Baross, J.A., 1990. Particulate DNA in smoker fluids: evidence for existence of microbial populations in hot hydrothermal systems. Appl. Environ. Microbiol., 56:1440-1447.

Szewzyk, U., Szewzyk, R., and Stenstrom, T.A., 1994. Thermophilic, anaerobic bacteria isolated from a deep borehole in granite in Sweden. Proc. Nat. Acad. Sci. USA, 91:1810-1813.

Thorseth, I.H., Torsvik, T., Furnes, H., and Muehlenbachs, K., 1995. Microbes play an important role in the alteration of oceanic crust. Chem. Geol., 126:137-146.

Widdel, F., 1992. The genus Thermodesulfabacterium. In Balows, A. (Ed.), The Prokaryotes (Vol. 4) (2nd ed.): Berlin (Springer), 3390-3392.

Wirsen, C.O., Jannasch, H.W., and Molyneaux, S.J., 1993. Chemosynthetic microbial activity at Mid-Atlantic Ridge hydrothermal vent sites. J. Geophys. Res., 98:9693-9703.

Zhou, J., Bruns, M.A., and Tiedje, J.M., 1996. DNA recovery from soils of diverse composition. Appl. Environ. Microbiol., 62:316-332.

Date of initial receipt: 3 June 1996

Date of acceptance: 13 December 1996

Ms 158SR-229 